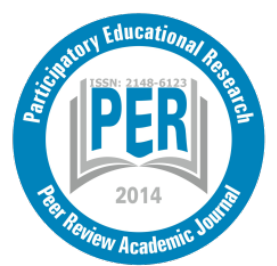

Participatory Educational Research (PER)

Vol. 7(2), pp. 230-240, August 2020

Available online at http://www.perjournal.com

ISSN: 2148-6123

http://dx.doi.org/10.17275/per.20.31.7.2

\title{
The mediating role of parenting efficacy in the association between preschool father-child relationship and parental stress
}

\author{
Neslihan DURMUŞOĞLU SALTALI* \\ Preschool Education Department, Ordu University, Ordu, Turkey \\ ORCID: 0000-0002-6912-7080
}

\begin{tabular}{|c|c|}
\hline Article history & chool children are \\
\hline $\begin{array}{l}\text { Received: } \\
18.02 .2020\end{array}$ & $\begin{array}{l}\text { their relationships with their parents. Until recently, when the child's } \\
\text { relationship with their parents is considered, the relationship with their }\end{array}$ \\
\hline $\begin{array}{l}\text { Received in revised form: } \\
01.05 .2020\end{array}$ & $\begin{array}{l}\text { mother has been taken into account, while recently the father-child } \\
\text { relationship has become one of the subjects that researchers are } \\
\text { increasingly interested in and thus is emphasized. In this study it was }\end{array}$ \\
\hline $\begin{array}{l}\text { Accepted: } \\
04.05 .2020\end{array}$ & $\begin{array}{l}\text { aimed to determine the mediating role of parenting efficacy in the } \\
\text { association between father-child relationship and parental stress in }\end{array}$ \\
\hline Key words: & preschool period. The research was carried out on fathers who have \\
\hline $\begin{array}{l}\text { Parental stress, } \\
\text { preschool father-child } \\
\text { relationship, } \\
\text { parenting efficacy }\end{array}$ & $\begin{array}{l}\text { study group consisted of } 421 \text { fathers selected among these fathers by } \\
\text { random sampling method. Child-Parent Relationship Scale, Parenting } \\
\text { Efficacy Scale and Parental Stress Scale were used to collect the research } \\
\text { data. The results obtained from the research are as follows: Firstly, } \\
\text { parental stress is a significant predictor of father-child relationship and } \\
\text { parenting efficacy. Secondly, parenting efficacy is a significant } \\
\text { predictor of father-child relationship. Finally, parenting efficacy has a } \\
\text { partial mediating role in the relationship between father-child } \\
\text { relationship and parenting efficacy. The results of the research may lead } \\
\text { to the development of policies and practices that support parenting } \\
\text { competence in terms of reducing the parental stress of fathers with } \\
\text { preschool children and improving their relationship with their children. }\end{array}$ \\
\hline
\end{tabular}

\section{Introduction}

The family is the smallest social unit of society, consisting of relationships that are affected by each other and affect each other. Socially, it contains relationships between husband and wife, parent-child and siblings. Especially for children between the ages of 0-6 viz. the preschoolers, the relationship with their parents is very important in the process of development, socialization and behavior acquisition (Meece \& Robinson, 2014). In fact, the family is the first stimulating social environment in the child's life. The behaviors that he / she is exposed to in the family environment, the relationships he / she establishes form the basis of his / her behaviors through constituting a role model to the child (Öngider, 2013). The importance of the relationship between the parent and the child in the development of the child has hitherto been included in many theories with different perspectives in the relevant literature. In terms of social learning theory of Bandura (1977), the relationship between parent and child is fundamental in

\footnotetext{
*Correspondence: ndsaltali@gmail.com
} 
the development of the child since it is highly influential in behavioral development offering a model to the child. According to Bronfenbrenner's theory of ecological systems (1979), the relationship of the child with the parent is one of the relationships that affect the child in the microsystem closely. In his psychoanalytic theory, Freud emphasizes the importance of preschool relationships and experiences in the personality development of the child (Geçtan, 1993). Mahler, on the other hand, stated in the separation-individuation theory that especially the father is attributed importance through father-child relationship as the baby is aware of the existence of someone other than the mother for the first time, and this has a crucial place in the child's separation-individuation process (Mahler \& La Perriere, 1965).

In light of the theoretical frame mentioned above, it can comfortably be uttered that it is important to consider the family-child relationship in scientific studies and to determine the factors that come into play accordingly. However, when studies on child-family relationships published in the last ten years are examined, it is observed that the father-child relationship, where the child-family relationship is mostly evaluated over the mother-child relationship, is thence among the less handled subjects compared to the mother-child relationship (Uzun \& Baran, 2015). To that end, when it comes to the family-child relationship, it is thought that the first person that comes to mind is the mother, that the mother is the first person responsible for the care of the child and the traditional family structure is effective. This is because in particular in relatively more traditional societies, it is witnessed that mothers play a more active role in developing children, develop a more active relationship, and fathers remain passive (Dönmez \& Ural, 2018). The mother, father, along with woman, male roles determined by the society and by the perception of the spouse's mother, father, woman and man roles are also influential in shaping the relations between mother and father and child (Güngör Aytar \& Kaytez, 2015). Less involvement of fathers and more of mothers in the development of the child may vary depending on the meanings that the relevant culture places on the roles of motherhood and fatherhood (Dönmez, 2019). One of the most important obstacles for fathers to establish active relationships with their children is their traditional concerns about the role of masculine men (Russel \& Hwang, 2010). That said the relationship with both parents has an important role in the child's development (Pleck, 2010; Meece \& Robinson, 2014). Yet it is seen that the role of paternity has changed in the societies in recent years, especially in Europe and America, fathers have started to have more active relationships with their children; they have a more active role in their care, and they have positive reflections on the development of the child in this change (Anliak, 2004). Changes in family structure brought changes and transformations in the roles and responsibilities of family members too. With the increase in the number of factories, the increase in the number of women in business life, women's rights have gained importance, the roles of women and men have changed (Russel \& Hwang, 2010; Mcbride, Rane, \& Bae, 2001). The increase in the number of out-of-home responsibilities with the entry of women into working life has caused male and female role definitions and duties to merge. Having said that the traditional family structure in Turkey and strong commitment to traditional roles (Erkan, 2015) are still visible. In this sense, it is important to consider the father-child relationship through research and to determine any related factors in this regard. Researches on father-child relationship are generally related to child-related factors and the effect of father-child relationship on child's development and behavior (Fagan \& Iglesias, 2000; Trautmann-Villalba, Gschwendt, Schmidt, \& Laucht, 2006; Pancsofar and Vernon-Feagans, 2010; Webster, Low, Siller \& Hackett, 2013, and others). Studies that investigate the father-child relationship in the context of parent-related factors are not yet sufficient in number. Considering the existing number of studies related to the father-child relationship, and the changes in the roles of the father in the preschool period, the father-child relationship was concentrated upon in the context of parenting stress in the present study. In the literature, it is encountered that studies on 
parenting stress are mostly carried out on mothers (Neece, Green, \& Baker, 2012), and that parental stress during preschool period is focused on in a limited number of studies (Brody \& Ge, 2001), and current studies are mostly conducted on families of children with special needs (Aydoğan \& Özbay, 2017; Pisula, \& Porębowicz-Dörsmann, 2017). In this study, parental stress differs in terms of addressing the father as a parent from the point of view of parents who have preschool children and evaluation of typically developing children in the context of their parents' stresses. In addition, when studies related to parental stress are examined in the literature, reciprocal interactions between parenting stress and parental factors seem to be associated, for example, parental depression (Gross, Shaw, \& Moilanen, 2008), marital distress (VanderValk et al., 2007), parenting practices (Brody \& Ge, 2001), family functioning (Pisula, \& Porębowicz-Dörsmann, 2017) and parental conflict (Allen et al., 2019). No study investigating the relationship between parenting stress and father-child relationship was found. Based on these points, it was intended to determine whether the predictor of parenting stress on the father caused by having a child in preschool period in the father-child relationship and if parenting efficacy has a mediator role in this relationship.

In the model established within the framework of the main purpose of the research, the following hypotheses were developed and tested.

- H1: Parenting stress of fathers in preschool period is the predictor of father-child relationship.

- H2: Parenting stresses of their fathers are a predictor of parenting competencies in preschool period.

- H3: Parenting competencies of fathers in preschool period are the predictor of fatherchild relationship.

- H4: Parenting efficacy of fathers in preschool period has an intermediary role in the relationship between their children and parenting stresses.

\section{Method}

\section{Research Design}

In this study, it was aimed to determine the mediating role of parenting efficacy in the association between father-child relationship and parental stress in preschool period. Thereupon it would be fair to state that the research has predictive correlation pattern that includes the analysis of direct and indirect effects. In the predictive correlation studies, the relationships between the variables are examined and the other is tried to be predicted based on one of the variables. The pattern can be defined not only to focus on direct effects but also to allow indirect effects to be tested (Büyüköztürk, Kılıç Çakmak, Erkan Akgün, Karadeniz, \& Demirel, 2012).

\section{Participants}

The random sampling method was used to obtain the participants. 421 fathers of preschool children in different cities of Turkey in the academic year 2019-2020 were included in the study. The study is composed of fathers with children between 48-72 months of age, who continued their formal or private pre-school education within the Ministry of National Education and who were typically developing. For the number of fathers to be included in the study Krejcie and Morgan's (1970) method to determine the number of samples based on the population number was referred to. According to the table, the sample size should be over 384 in the studies that will represent more than 100000 universes. In this study, data was obtained 
from 421 fathers and through this sample width criterion was fulfilled. The average age of the fathers participating in the study is $37.52(\mathrm{ss}=4.61)$ in years and the average age of their children is 65.32 ( $\mathrm{ss}=3.82$ ) in months. Of the children included in the study, 207 attend preprimary education in public schools and 214 in private schools. The distribution of fathers according to their educational status is as follows: 208 are university graduates and above, 121 are high school graduates and 92 are primary school graduates.

\section{Instruments}

\section{Personal Information Form}

In the research, Personal Information Form was used to collect demographic data of the participants. The form includes the age of the father, the level of education, the age of the child attending pre-school education in months, and the type of school in which the child continues.

\section{Child-Parent Relationship Scale (Father Form)}

In this study, a version of Child Parent Relationship Scale, developed by Pianta (1992), was resorted to where its Turkish adaptation, validity and reliability studies were performed on fathers who have children in preschool period by Long and Baran (2015). The scale is a selfassessment tool that fathers fill out based on their relationship with their children. In the Turkish version of the scale, where the validity and reliability study were conducted, there are three subdimensions, namely positive relationship, conflict and incompatibility, similar to the original scale. The scale can also be used on the total score values of the father-child relationship. The scale is a 5-point Likert-type scale and is answered using the ranges: (1) Absolutely not suitable, (5) Absolutely very appropriate. The form of the scale, adapted for fathers, consists of 23 items. In the study, the father-child relationship was evaluated on the scale's total score. The fatherchild relationship total score was obtained by collecting the negative correlation items between incompatibility and conflict subscale items by reverse coding and the scores obtained with the positive relationship subscale scores. In this study, the reliability coefficient for the father-child relationship scale total scores was calculated as .72. The father-child relationship score that can be obtained from the scale varies between 23 and 115, and high scores indicate positive relationships between father and child.

\section{Parental Stress Scale}

In the study, parental stress scale developed by Berry, \& Jones (1995) was made use of to evaluate fathers' parental stress. Turkish validity and reliability studies were also conducted within the scope of the research. The scale is a self-assessment tool, in which parents evaluate themselves through 18 items based on their relationship with their children. The scale includes a five-point Likert assessment ranging from strongly disagree to strongly agree. Eight items (1, $2,5,6,7,8,17$, and 18) are inversely scored on the scale. The results of the validity and reliability study conducted by Berry and Jones (1995) of the scale, the variance rate explained by the 18-item form under one factor was determined as .49. The internal consistency coefficient for the entire scale was calculated as Cronbach $\alpha=0.82$. In this study, the reliability coefficient of the scale was calculated as .81. It was observed that the factor load values of the items in the scale ranged between .70 and .85 , and the item total correlations varied between .73 and .86 . The lowest score that can be obtained from the scale is 18 , and the highest score is 90. The increase in the score obtained from the scale indicates an increase in parental stress. 


\section{Parenting Efficacy Scale}

This scale was developed by Caprara, Regalia, Scabini, Barbanelli and Bandura (2004). The original form of the scale consists of 12 items and one dimension is aimed to measure parents' parenting skills. In this study, a version of the scale, which was adapted to Turkish by Demir and Gündüz (2014), and whose validity and reliability studies were completed, was utilized. As a result of the Turkish validity and reliability study, a one-dimensional scale consisting of 11 items was obtained and the explained variance was determined as .55 . In the analysis for the reliability of the scale, the cronbach alpha reliability coefficient was found as .91. The scale includes 7-point Likert-type values, the lowest score that can be obtained from the scale is 11 , and the highest score is 77 . In this study, the reliability coefficient of the measurement tool was calculated as .89.

\section{Statistical analysis}

In this study, the relationships between the variables were examined by Pearson correlation analysis. The determination of whether parenting efficacy has a mediating effect in the relationship between parental stress and father-child relationship was carried out by stepwise regression analysis. The method of Baron and Kenny (1986) was used in the analysis to see the mediation role of parenting efficacy. Baron and Kenny specify some conditions in order to be able to talk about the intermediary effect. The first condition is that the predictor variable (parenting stress) should have a significant effect on the predicted variable (fatherchild relationship). The second condition is that the predictive variable (parental stress) should have a significant impact on the mediating variable (parenting efficacy). The third condition is that the mediating variable (parenting efficacy) should have a significant effect on the predicted variable (father-child relationship). After these conditions are met, the effect of both predictor and intermediary variables on the predicted variable as independent variables should be calculated. As a result, the role of the predictive variable on the predicted variable decreases as "partial", and if this effect becomes meaningless, the role of "full" mediation is mentioned.

Prior to the regression analysis the data were evaluated as to the numbers required for the regression analysis. In this framework, skewness and kurtosis values were examined to determine whether the data showed normal distribution. At the end of the examination, the skewness value of the father-child relationship score was figured out as 0.56 and the kurtosis value as -0.33 ; it was observed that the skewness value of the parental stress score was 0.14 , the kurtosis value was -0.67 , and the parental competency score was skewness value -0.46 and the kurtosis value was -0.69 . It was observed that the kurtosis and skewness values of the data were distributed between +1.96 and -1.96 (Büyüköztürk, 2006), which are shown as criteria for normal distribution. Besides, tolerance and VIF values of the multiple connection problem of the data were examined. When the VIF value is equal to or greater than 10 and tolerance values are greater than 0.2, the model has multiple linear connection problems (Pallant, 2005). The VIF values were found to be 1.602 and the tolerance value was 0.624 , and there was no multiple linear connection problem in the data set. Then progressive regression analysis was initiated. A macro process developed by Hayes (2019) with the intention of being used in addition to the SPSS program was preferred to evaluate the effect of the broker variable. IBM statistics 21.0 package program was used in statistics. The significance of the mediating effect was evaluated with the Sobel test. 


\section{Results}

Firstly, the correlation coefficient values of the Pearson Moments Product analysis was performed to see the relationships between the variables in the study and the arithmetic mean and standard deviation values of the variables are given in Table 1.

Table 1. Descriptive and relational statistics for all variables

\begin{tabular}{lllllll}
\hline & $\mathbf{n}$ & Mean & Sd & PS & PE & FCR \\
\hline 1. Parental Stress (PS) & 421 & 43.06 & 8.25 & 1 & & \\
2. Parenting Efficacy (PE) & 421 & 44.82 & 6.96 & $-.613^{* *}$ & 1 & \\
3. Father-Child Relationship (FCR) & 421 & 74.98 & 6.21 & $-.730^{* *}$ & $.573^{* *}$ & 1 \\
\hline
\end{tabular}

When Table 1 is analyzed, it is witnessed that there is a high level of negative relationship between father-child relationship and parental stress, and a moderate positive relationship between parenting efficacy. Additionally, a moderate negative correlation was detected between parenting stress and parenting efficacy. The stepwise regression analysis results to determine whether parenting efficacy has an intermediary role in the relationship between parenting stress and father-child relationship are also presented in Table 2.

Table 2. Stepwise regression analysis on the mediating role of parenting efficacy in the association between father-child relationship and parental stress.

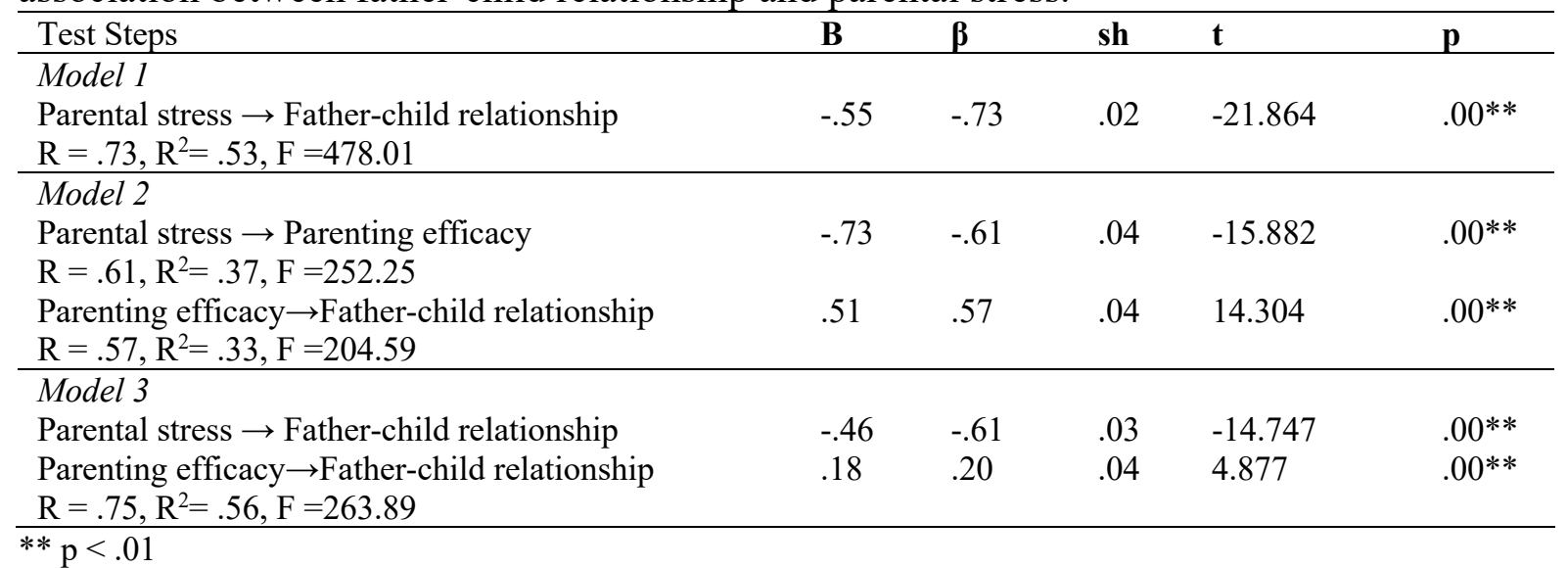

When Table 2 is analyzed, it is seen in Model 1 that parental stress is a significant predictor of father-child relationship $(\beta=-.73, \mathrm{R} 2=.53)$. In this case, H1 hypothesis was accepted. In Model 2, parental stress is a significant predictor of parenting efficacy $(\beta=-.61, \mathrm{R} 2=.37$ and $\mathrm{H} 2$ hypothesis accepted) and parenting efficacy is a significant predictor of father-child relationship ( $\beta=.57, \mathrm{R} 2=.33$ and $\mathrm{H} 3$ hypothesis accepted). In Model 3 , it is seen that the explanation of parenting stress in the father-child relationship decreases when parenting efficacy is added to the model $(\beta=-.73, \mathrm{R} 2=.53$ for Model 1 and $\beta=-.61, \mathrm{R} 2=.37$ for Model $3)$. In this case, it is understood that parenting efficacy has a partial mediating role in the relationship between father-child relationship and parenting stress. In order for the partial mediation status determined in accordance with the relevant literature to be meaningful, the decrease in the variance explained by the independent variable should be determined by tests such as the Sobel test (Sobel, 1982). For this reason, so as to determine the significance of the partial mediation role of parenting efficacy in Model 3, the sobel test was applied and the $\mathrm{z}$ value was calculated as 3.09 as a result of the test. The sobel test results obtained also displayed the significance of the partial mediating role of parenting efficacy in the relationship between father-child relationship and parental stress $(\mathrm{p}<0.01)$. H4 hypothesis is accepted as partial. 


\section{Discussion and Conclusion}

In this study, it was aimed to determine the mediating role of parenting efficacy in the relationship between father-child relationship and parental stress in preschool period. In the context of this aim, first of all, the relationships between research variables are examined. Statistics in this context demonstrated that there is a negative relationship between father-child relationship and parental stress, and parental stress is a significant predictor of father-child relationship. The decrease in parental stress scores in the new preschool period positively impacts the father-child relationship scores. In the literature, it is underpinned that studies related to parental stress are generally conducted on families with disadvantaged children, whereas typically developing children may also experience parental stress in their families (Aydoğan \& Özbay, 2017) and it is suggested that this should be addressed in the related research. Parenting stress is defined as the physical and psychological responses to the parents' interaction with the child and adapting to the tasks required by being a parent. The first result of the study can be interpreted in the way that fathers with low parental stress internalize the responsibilities of being a parent and reflect this positively on their relationship with their children. Smith (2017) found that parental stress influences parents' reactions to their children's behavior. Glueck (2017) conducted a study on parents with children between the ages of 6-12 and investigated the effect of his therapy on parental behaviors via applying child interaction therapy to parents. The result of this study exhibited that parent-child interaction therapy reduced parental stress and enhanced interactions between parent-child. Berryhill, Soloski, Durtschi, and Adams (2016) found that parenting stress on parents who have 1, 3, 5 year old children also affected the relationship between the spouses and the parent-child relationship in the family. These results are similar to our research findings.

The second result of the study is that parental stress is inversely correlated with parenting efficacy and predicts parenting efficacy. This result can be interpreted as the decrease in parental stress scores positively affects parenting efficacy. In the parental stress model developed by Abidin (1982), factors related to parental perception of parenthood are shown as one of the sources of parental stress. Factors such as traditional father role expectations (Anliak, 2004) and gatekeeping mother attitudes (Dönmez \& Ural, 2018) that the father is exposed to may be effective in decreasing father's parenting efficacy and increasing parental stress. Tahmassian, Anari and Fathabadi (2011), in their study on Iranian mothers, reached the conclusion that as parenting efficacy increases, mothers' stress decreases. Although this result was carried out on the mother as a parent, it is in line with our research results. In addition, the results showing that high parental stress scores in the literature are related to low effective, responsive, supportive parental behavior scores are also in line with our research results (Belsky, Woodworth, \& Crnic, 1996; Coldwell, Pike, Dunn, 2006; Crnic, Gaze \& Hoffman, 2005).

The third result of the study is that parenting efficacy is related to the father-child relationship and predicts the father-child relationship. Conrad, Gross, Fogg, \& Ruchala (1992) argue that parenting efficacy is related to knowing about the child's development and knowing how to communicate and relate to the child. In parallel with this information, Coleman and Karraker (1997) found out that parenting efficacy positively influences the behavior of the parent towards the child and increases the quality time spent and communication with the child. These results support our research findings.

The final result of the research is that parenting efficacy has a partial role in the relationship between father-child relationship and fathers' parental stress in preschool period. This situation can be interpreted as the negative effect of parenting stress on father-child relationship in 
preschool period, decreasing parenting efficacy. Based on this result, parenting efficacy seems to act as a protective factor on the father-child relationship by reducing the risk factor that parental stress creates on the father-child relationship. In addition to that, the result of the study conducted by Karageyik (2019) is consistent with our findings that the parent-child communication has a full mediating role in the relationship between the parental stress and parenting efficacy of parents with children during adolescence.

There are some limitations of the research. Parenting data discussed in the study are limited to fathers who have children in preschool period. In future studies, studies evaluating the parenting behavior of both parents and evaluating parents with children in different age groups can be conducted. The data obtained in the study were obtained from the fathers by self-evaluation. In future researches, it is recommended to support and enrich the data with varying data collection methods.

In future researches, different variables that may mediate the relationship between parenting stress and father-child relationship can be studied. By developing programs aimed at increasing parenting efficacy, the effectiveness of parenting stress and father-child relationship can be investigated. Educational support to increase parenting efficacy can be provided for fathers in reducing parental stress by psychologists, family counselors and healthcare professionals. In the field of education, input can be added to the educational content targeting to improve the father-child relationship, and to increase parenting efficacy.

\section{References}

Abidin, R. R. (1982). Parenting stress and the utilization of pediatric services. Children's Health Care, 11(2), 70-73. https://doi.org/10.1207/s15326888chc1102_5

Allen, A.L., Manning, W.D., Longmore, M.A. and Giordano, P.C. (2019), Young adult parents' work-family conflict: the roles of parenting stress and parental conflict, Contemporary Perspectives in Family Research, 15, 1-16. https://doi.org/10.1108/S1530353520190000015001

Anliak, S. (2004). The importance of father and male teacher in child's life in the period of preschool. Ege Journal of Education, 5(1), 25-33.

Aydoğan, D., \& Özbay, Y. (2017). The Parenting Stress Scale: The validity and the reliability study. International Journal of Early Childhood Education Studies, 2(2), 24-38.

Bandura, A. (1977). Social learning theory. Englewood Cliffs, NJ: Prentice-Hall.

Baron, R. M., \& Kenny, D. A. (1986). The moderator-mediator variable distinction in social psychological research: Conceptual, strategic, and statistical considerations. Journal of Personality and Social Psychology, 51(6), 1173. https://doi.org/10.1037//00223514.51.6.1173

Belsky, J., Woodworth, S., \& Crnic, K. (1996). Trouble in the second year: Three questions about family interaction. Child Development, 67(2), 556-578. https://doi.org/10.1111/j.1467-8624.1996.tb01751.x

Berryhill, M. B., Soloski, K. L., Durtschi, J. A. \& Adams, R. R. (2016). Family process: Early child emotionality, parenting stress, and couple relationship quality. Personal Relationships, 23(1), 23-41. https://doi.org/10.1111/pere.12109

Berry, J. O., \& Jones, W. H. (1995). The Parental Stress Scale: Initial psychometric evidence. Journal of Social and Personal Relationships, 12(3), 463472. https://doi.org/10.1177/0265407595123009

Brody, G. H., \& Ge, X. (2001). Linking parenting processes and self-regulation to psychological functioning and alcohol use during early adolescence. 
Journal of Family Psychology, 15(1), 82-94. https://doi.org/10.1037/08933200.15.1.82

Bronfenbrenner, U. (1979). The Ecology of Human Development. Cambridge, MA: Harvard University Press.

Büyüköztürk, Ş. (2006). Data analysis for social sciences. Ankara: PegemA Publications.

Büyüköztürk, Ş., Kılıç Çakmak, E., Akgün, Ö.E., Karadeniz, Ş., \& Demirel, F. (2012). Scientific Research Methods (12. Edition). Ankara: PegemA Publications.

Caprara, G., Regalia, C., Scabini, E., Barbanelli, C., \& Bandura A. (2004). Assessment of Filial, Parental, Marital, and Collective Family Efficacy Beliefs. European Journal of Psychological Assessment, 20(4), 247-26. https://doi.org/10.1027/1015-5759.20.4.247

Coldwell, J., Pike, A., \& Dunn, J. (2006). Household chaos-links with parenting and child behaviour. Journal of Child Psychology and Psychiatry, 47(11), 1116-1122. https://doi.org/10.1111/j.1469-7610.2006.01655.x

Coleman, P. K., \& Karraker, K. H. (1998). Self-efficacy and parenting quality: Findings and $\begin{array}{llll}\text { future applications. Developmental review, 18(1), 47-85. } & \text {. }\end{array}$ https://doi.org/10.1006/drev.1997.0448

Crnic, K. A., Gaze, C., \& Hoffman, C. (2005). Cumulative parenting stress across the preschool period: Relations to maternal parenting and child behavior at age 5. Infant and Child Development, 14(2), 117-132. https://doi.org/10.1002/icd.384

Conrad, B., Gross, D., Fogg, L., \& Ruchala, P. (1992). Maternal confidence, knowledge, and quality of mother-toddler interactions: A preliminary study. Infant Mental Health Journal, 13(4), 353-362.

Demir, S., \& Gündüz, B. (2014). Adaptation of the parental self-efficacy scale: the study of validity and reliability. Mustafa Kemal University Journal of Social Sciences Institute, 11(25), 309-322.

Dönmez, Ö. \& Ural, O. (2018 October 22-24). Development of Maternal Gatekeeping Scale and validity and reliability study. International IV. Child Development Congress. Hacettepe University Cultural Center, Ankara.

Dönmez, Ö. (2019). Development of maternal gatekeeping scale and examining interaction behaviors of mothers and fathers of preschool aged children (Publication number. 560462) [Master thesis, Marmara University]. CoHE Dissertation Documentation System.

Erkan, N. S. (2015). Basic concepts of family and family education. In: Z. F. Temel (Ed.). Family education and family participation studies in early childhood, (pp. 3-43), Ani Publishing.

Fagan, J., \& Iglesias, A. (2000). The relationship between fathers' and children's communication skills and children's behavior problems: a study of Head Start children. Early Education and Development, 11(3), 307-320. https://doi.org/10.1207/s15566935eed1103_5

Geçtan, E. (1993). Psychoanalysis and later. (Fifth ed.), İstanbul: Remzi Bookstore.

Glueck, B. M. A. (2017). The relationship between parent-child interaction therapy and parenting stress. [Doctorat Dissertation, Hofstra University]. ProQuest Dissertations \& Theses Global.

Gross, H. E., Shaw, D. S., \& Moilanen, K. L. (2008). Reciprocal associations between boys' externalizing problems and mothers' depressive symptoms. Journal of Abnormal Child Psychology, 36(5), 693-709. https://doi.org/10.1007/s10802-008-9224-x

Güngör Aytar, A., \& Kaytez, N. (2015). Communication in the family and its effects on children. In: A. Güngör Aytar (Ed.) Effective Communication. (pp. 95-119), Ankara: Hedef CS Publication 
Hayes, A.F. (2019). Model Templates for PROCESS for SPSS and SAS. Available online: http://afhayes.com/spss-sasand-mplus-macros-and-code.html (accessed on 28 December 2019).

Karageyik, K. (2019). The study of the parenting stress in terms of parental self- efficacy and communication of parents with their children (Publication number. 562898) [Master thesis, Gaziantep University]. CoHE Dissertation Documentation System.

Krejcie, R.V., \& Morgan, D.W. (1970). Determining sample size for research activities. Educational and Psychological Measurement, 30(3), 607-610. https://doi.org/10.1177/001316447003000308

Mahler, M. S., \& La Perriere, K. (1965). Mother-child interaction during separationindividuation. The Psychoanalytic Quarterly, 34(4), 483-498. https://doi.org/10.1080/21674086.1965.11926361

McBride, B. A., Rane, T. R., \& Bae, J. H. (2001). Intervening with teachers to encourage father/male involvement in early childhood programs. Early Childhood Research Quarterly, 16(1), 77-93. https://doi.org/10.1016/S0885-2006(01)00087-4

Meece, D., \& Robinson, C.M. (2014). Father-child interaction: associations with self-control and aggression among 4.5-year-olds. Early Child Development and Care, 184(5), 783794. https://doi.org/10.1080/03004430.2013.818990

Neece, C. L., Green, S. A., \& Baker, B. L. (2012). Parenting stress and child behavior problems: A transactional relationship across time. American Journal on Intellectual and Developmental Disabilities, 117(1), 48-66. https://doi.org/10.1352/1944-7558117.1.48

Öngider, N. (2013). Relationship Between Parents and Preschool Children. Current Approaches in Psychiatry, 5(4), 420-440. https://doi.org/10.5455/cap.20130527

Pallant, J. (2005). SPSS survival guide: A step by step guide to data analysis using SPSS for Windows. New York: Open University Press.

Pancsofar, N., \& Vernon-Feagans, L. (2010). Fathers' early contributions to children language development in families from low income rural communities. Early Childhood Research Quarterly, 25(4), 450-463. https://doi.org/10.1016/j.ecresq.2010.02.001

Pianta, R. (1992). Child Parent Relationship Scale. Charlottesville, VA: University of Virginia. Center for Advanced Studies on Teaching and Learning.

Pisula, E., \& Porębowicz-Dörsmann, A. (2017). Family functioning, parenting stress and quality of life in mothers and fathers of Polish children with high functioning autism or $\begin{array}{llll}\text { Asperger } & \text { syndrome. } & \text { PloS } & \text { one, }\end{array}$ https://doi.org/10.1371/journal.pone.0186536

Pleck, J. (2010). Fatherhood and masculinity. In: ME Lamb (Ed.), The role of the father in child development. Hoboken, NJ: John Wiley \& Sons.

Russell, G., \& Hwang, P. (2010). The impact of workplace practices on father involvement. In: ME Lamb (Ed.), The Role of the Father in Child Development. Hoboken, NJ: John Wiley \& Sons.

Sobel, M. E. (1982). Asymptotic confidence intervals for indirect effects in structural equation models. Sociological Methodology, 13, 290-312. https://doi.org/10.2307/270723

Smith, E. (2017). The role of parental self-efficacy, hardiness, parenting stress in predicting parenting behaviors. [Doctorate Thesis, University od Southern Mississipi]. https://aquila.usm.edu/dissertations/1452

Tahmassian, K., Anari, M. A., \& Fathabadi, M. (2011). The influencing factors of parenting stress in Iranian mothers. European Psychiatry, 26(1), 19-24. https://doi.org/10.1016/S0924-9338(11)72836-X

Trautmann-Villalba, P., Gschwendt, M., Schmidt, M. H., \& Laucht, M. (2006). Father-infant interaction patterns as precursors of children's later externalizing behavior problems. 
European Archives of Psychiatry and Clinical Neuroscience, 256(6), 344-349. https://doi.org/10.1007/s00406-006-0642-x

Uzun, H., \& Baran, G. (2015). A study to evaluate validity and reliability of child parent relationship scale for fathers who have children in preschool period. The Journal of International Education Science, 2(3), 30-40. https://doi.org/10.1007/s00406-0060642-x

VanderValk, I., de Goede, M., Spruijt, E., \& Meeus, W. (2007). A longitudinal study on transactional relations between parental marital distress and adolescent emotional adjustment. Adolescence, 42(165), 116-136.

Webster, L. L., Low, J., Siller, C., \& Hackett, R. K. (2013). Understanding the contribution of a father's warmth on his child's social skills. Fathering: A journal of theory, research, and practice about men as fathers, 11(1), 90-113. https://doi.org/10.3149/fth.1101.90 